\title{
Development of Problem-Based Learning and Inquiry (PBL) Learning Methods in the Form of Mass Media- Based Case Studies on Integrity and Anti-Corruption Subject
}

\author{
Dewi Anggraini ${ }^{1 *}$ Didi Rahmadi ${ }^{2}$
}

\author{
${ }^{1}$ Department of Political Science, Faculty of Social and Political Sciences, Andalas University \\ ${ }^{2}$ Department of Political Science, Faculty of Social and Political Sciences, Universitas Muhammadiyah Sumatera \\ Barat \\ *Corresponding author. Email : dewianggraini_81@yahoo.com
}

\begin{abstract}
Integrity and Anti-Corruption subject are entered into the KKNI based curriculum in 2018 and are mandatory subject at Political science department given to second semester students. In this subject we are discussed several important topics on the concept of integrity and anti-corruption attitudes which are a common phenomenon in the political system and democratic state. This course also examines why corruption behavior occurs massively in Indonesia, as well as efforts made by the government in dealing with integrity enforcement issues and anti-corruption attitudes. The learning process in this subject is divided into two models of learning. First, a face-to-face SCL learning model in the classroom conducted for 7 (seven) meetings before the Mid Term Exam. Second, the online lecture model uses Whatsapp Group (WAG) that have been established at the first meeting. In this online lecture process, there were 7 (seven) meetings after Mid Term Exam. This subject was attended by 47 students. For this semester, the spread of 70 $\%$ students' score ranges from 70-95 (B to the A in the letter grade), and 30\% get a $\mathrm{C}$ to B-grade. In addition, there are some students who are interested in planning the writing of their research proposals with the theme of integrity and anti-corruption. The learning process using the problem base learning and inquiry method can be applied to the lecture process face-to-face or by online methods. However, in online lectures lecturers have difficulty in conducting control over the active involvement of each student in responding to the discussion activities of the case that have been agreed together.
\end{abstract}

Keywords: Integrity, anti-corruption, case studies

\section{INTRODUCTION}

Integrity and Anti-Corruption subject is entered to curriculum in 2018 and mandatory subject given to semester II students in the Department of Political Science. In this course we are discussed several important topics on the concept of integrity and anticorruption attitudes which are a common phenomenon in the political system and democratic state. This course also examines why corruption behavior occurs in Indonesia and the world, as well as efforts made by the government in dealing with integrity enforcement issues and anti-corruption attitudes. In addition, the discussion in detail is more directed at the Concept of Integrity in general, Integrity in Politics, Character and the key nature of Political Integrity, Frame work of Integrity
System, Pillars of National Integrity. Integrity in several public sectors, conception of Corruption and The Causes of Corruption, Impact of Corruption, Corruption in the Public Sector, Political Corruption and Corruption Eradication Strategy.

It is expected that through this subject students are able to understand and explain; relevant concepts in explaining and addressing the integrity and anticorruption issues that exist in Indonesia that are associated with the relation of political power. This course is also expected to produce student competencies, especially in compiling short assignments and essays so as to improve their ability to write their ideas, related to the subject topics contained in "RPS", such as the implications of integrity and anti-corruption values in universities, integrity and anti-corruption attitudes in the 
world of work as well as what efforts can be made to eradicate corruption that can be done by students as agents of change. In addition, this course is also expected to be able to conduct case studies of mediabased corruption cases, from the case study students learn to identify cases related to the type of corruption committed, chronological cases, actors, state losses and the development of cases that occur as well as what solutions can be offered by the student.

Learning achievements in this curriculum of the study program include: Mastering the basics of integrity theory/concepts in political relations and developing science in accordance with the development of science and technology for society, upholding the value of humanity in carrying out duties based on religion, morals, and ethics, contributing to the improvement of the quality of public life, national, state, and civilization progress based on Pancasila, cooperating and having social sensitivity and care for the community and the environment, able to demonstrate independent, quality, and measurable performance, Able to make decisions appropriately in the context of problem solving in the field of expertise, based on the results of information and data analysis, able to maintain and develop a network of work with advisers, colleagues, colleagues both inside and outside its institutions and stake holders, able to analyze integrity behavior and anti-corruption dynamics that occur in legislative institutions, executives and judiciary, and able to advocate policies related to the development of integrity and anticorruption in Indonesia.

To achieve this ability, in the process of learning we use primary teaching materials such as textbooks, journals, state regulations, mass media content (in print and online news), as well as utilizing social media. As for secondary teaching materials using power points, plano paper and meta plans as well as audiovisual, case studies, problem based learning and others that support student centered learning (SCL) learning methods.

The learning methods implemented in the integrity and anti-corruption subject learning process have not been fully sourced in the SCL learning method. In the learning process we still maintain the Teacher Centered Learning (TCL) method. Where, TCL is at once combined with the SCL method. The percentage is $40 \%$ TCL, where lecturers still give lecture methods at the beginning of lectures as an introduction to learning topics and at the end of lectures as a conclusion of discussions between students and 60\% SCL where the material has used much more attractive media such as audiovisual, plano paper, class discussion according to the topics contained in RPS as well as news related to integrity and anti-corruption values found in the mass media both in print and online, national and local, all of which support SCL-based learning.

While the teaching materials in this course are still directed by curriculum and modules developed by the
Corruption Eradication Commission, namely the Integrity Materials Module for the Public and the AntiCorruption Education Book for Universities. Where the two modules are modified by lecturers with adjustments to the local context and by combining investigative techniques in cases of corruption and deviation of integrity values that occur in the midst of society, especially in state and private institutions.

For assessment is divided into two categories. first, assessment of results consisting of Midterm Exams (25\%) and Final Semester Exams (30\%). Second, assessment of processes consisting of Individual Tasks and presentations (quality of work, critical thinking and logical argument, originality and novelty, initiative/participation) 20\%, Group Tasks and presentations (technical and analytical skills, teamwork, communication, originality and novelty, initiative/participation) $15 \%$ and Writing in mass media related to lecture topics as much as $10 \%$. There are several student problems found during the study process until the second midterm exams 2019-2020. Lack of soft skills that students have in the development of topics contained in RPS, the lack of ability of students to communicate and provide views at every lecture meeting and the lack of interest in students to write in the mass media as well as the lack of ability of students to conduct case analysis in cases of integrity lapses and corruption cases. Therefore, after the midterm exam will take place there will be changes in some learning topics as well as changes in the assessment element, especially the element of the process with an additional assessment of $10 \%$ for students whose writing is published in the mass media both local and national

The assessment of student learning achievement has fully referred to the SCL method in which the process of providing a learning evaluation is not only determined by the final results of the student. The assessment in this course is not only seen from the final results of the midterm exams, assignments, and final exams but is seen from the whole process in attending this course (attendance, activeness in class discussions). Not only in the classroom, the assessment process is also seen from student activities that support the strengthening of the scientific such as participating in organizing and other student activities.

Because this integrity and anti-corruption subject is a new curriculum whose implementation has only been carried out in the second semester of the 2019-2020, then the distribution of the final score of students in the last semester does not exist as a comparison material.

\section{METHODS}

Related to the learning plan for the latest RPS, based on the results of the evaluation of learning in the middle of this semester, then there is an additional discussion topic for future learning, especially regarding the discussion of the regulatory package on Corruption 
Prevention, the application of Integrity values in the community, then there will also be a discussion about the success story in the application of integrity and anticorruption values in universities and also in several municipalities and nagari in West Sumatra. In addition, it will also be discussed on the latest cases and issues regarding the eradication of corruption in Indonesia. There are several learning plans that want to be implemented in an effort to improve learning achievement, First, identify the characteristics of student learning through pretest and post test implemented before and after the lecture process is carried out to measure the knowledge and ability of students in understanding the topics in subject RPS. Second, hold a study contract based on the active participation of students. Third, design a classroom atmosphere that can interact with the entire class. Fourth, at the beginning of the lecture, the lecturer gives an introduction to the material as well as throwing various issues or cases so as to stimulate the student to issue his opinion in the form of a class discussion. Fifth, open the widest possible discussion related to the topic of learning.

For the development of learning methods, the learning team chose to use problem-based learning and inquiry (PBL) combined with media-based integrity and corruption case investigation techniques that occur in Indonesia generally and in West Sumatra in particular. PBL itself is a learning strategy that groups students in small discussion groups. In the discussion group they are required to learn themselves by doing what they get after the development team gives the topic to discuss together ${ }^{1}$.

PBL is carried out in various ways, in Education Quality Development and Assurance Research (PPMP) will be adopted PBL model "seven jumps" applied at Andalas University especially to the Faculty of Medicine $^{2}$ PBL is carried out in various ways, in PPMP research will be adopted PBL model "seven jumps" applied at Andalas University especially to the Faculty of Medicine but made modifications in such a way that can be applied to social humanities research. This PBL method begins with the provision of lecture topics contained in RPS to be sanctified at each meeting, students are given modules and handbooks containing lecture materials. The measures of implementation of PBL are as follows: a) Students are welcome to choose their respective seats on seats that have been arranged in a way that facilitates group discussions to take place. b) Students choose the chairman of the group who will act as the moderator of the discussion, and minutes to

\footnotetext{
${ }^{1}$ Ward, 2002, Stepien, dkk 1993 in www.lubisgrafura.wordpress.com

${ }^{2}$ Afrizal, dkk. 2014. Panduan Praktis Pelaksanaan Student Centered Learning (SCL). LP3M Universitas Andalas
}

record the discussion on the existing sheet of paper. Roles are played for each scenario. The appropriate flip chart or whiteboard should be used to record the discussion process. c) At the beginning of the session, one of the students reads the topic to all members of the group or each student reads the topic individually. The Seven Jumps Stage is as follows: Step 1; Identifying and describing incomprehensible terms found in lecture topics, the minutes record a list of terms that remain unexplained after the discussion. Step 2; Defining the issue or issue to be discussed, students may have different views on the issue, but all should be considered, the clerk noted the list of agreed issues. Step 3; "Brainstorming" is a session to discuss issues that have been agreed to be discussed. Students discuss possible explanations or assumptions that may explain the problems set out in step 2, using knowledge they have previously had. Students cooperate by using their own knowledge and identifying areas of knowledge that have not been properly explained or not enough. The clerk noted all the results of the discussion. Step 4; Review the discussion reviews in steps 2 and 3. Then set the explanation into a tentative solution, which is restructured in the form of a scheme. Step 5; Formulating learning goals, groups reaching consensus on learning goals, tutors ensuring focused, achievable, comprehensive, and precise learning goals. Step 6; SelfStudy. All students collect information related to each learning objective. This step is done outside of the PBL tutorial. Lecturers or tutors need to give enough time for students to self-study in order for all learning goals to be achieved. Step 7; The group re-gathered for a discussion (group discussion). Students share and discuss their selfstudy results. Tutors/co-coordinators evaluate student learning outcomes. The role of PBL tutors/cocoordinators in facilitating the discussion process, is as follows: a) help the group chairman maintain the dynamics of the group; b) ensure the group is able to complete the established learning objectives; c) tutors may need to take a more active role in the tutorial process to ensure that all students have done their job appropriately; d) help suggest a self-study presentation format suitable for group members; e) encourage students to evaluate their understanding of the material. Tutors can do this by asking open questions, encouraging students to ask questions, to explain the material in their own words, with images and schemes; and f) provide feedback to students about their participation in the tutorial process and about achieving learning goals ${ }^{3}$.

Assessment of learning achievements will still refer to the entire learning process. Certainly the assessment process is the value of systematically obtained learning evaluations both cognitively, psychomotorly, and affective from the beginning and

\footnotetext{
${ }^{3}$ Ibid.
} 
end of learning. The assessment plan adopts Paulo Freire pedagogy learning which focuses on the overall participation process.

The parameters of PTK that used can be seen in the table below:

\begin{tabular}{|l|l|l|}
\hline No. & Assessment Components & Score (\%) \\
\hline 1. & Assessment result & $25 \%$ \\
\hline a. & Mid Term Test & $30 \%$ \\
b. & Final Term Test & \\
2. & Assessment process & $20 \%$ \\
\hline a. & Intrapersonal skill dimensions & $15 \%$ \\
\hline b. & Softskill interpersonal attributes & $10 \%$ \\
\hline c. & Attitude and value dimensions & $100 \%$ \\
\hline & Total & \\
\hline
\end{tabular}

The curriculum used in this subject has used KKNI curriculum, which in the development of this curriculum has been based on the profile of graduates. In the Political Science Department there are 5 (five) graduate profiles assigned that are academics, political practitioners, election organizers, bureaucrats and NGOs.

The development of learning technology is largely still using various learning media provided by the university, such as using laptops, in focus and audio visuals, but still modified by the development team in making learning technology that follows the flow of student development, the development team also utilizes Whatsapp application as a medium of student interaction with lecturers and their inter-students in the learning process. In using of media social such as whatsapp group, both lecturer materials and presentation materials from students should be uploaded to the WAG the day before the face-to-face lecture is conducted, so that there is time together to read the materials for the next lecture, and this facilitates the student's understanding of the material to be taught at the next meeting.

The assessment in this subject is not only based on the standard of results, but also based on the standard of the process, there is even additional value/point for students who can write in the mass media both local and national related to the topics contained in rps that have been shared before.

\section{RESULT AND DISCUSSION}

The learning process in this subject will be divided into two learning models. First, a face-to-face SCL learning model in the classroom conducted for 7 (seven) meetings before the Mid Semester Exam. Second, the online lecture model uses Whatsapp Group (WAG) courses that have been established at the first meeting. In this online lecture process, there were 7 (seven) meetings after UTS. This A class subject was attended by 47 students. The learning process in this subject is conducted by combining student center learning (SCL) method with problem-based learning and inquiry (PBL) approach with Teacher center learning (TCL) method on certain topics, especially at two meetings at the beginning of the lecture process, because lecturers explain concepts related to the material in RPS as a whole. In addition, in the learning process it also uses primary teaching materials such as textbooks, journals, mass media clippings both print and online and other secondary sources. While the learning facilities use power points, plano paper and meta plan and audiovisual material, mass media case tudy, and others.

At the meeting before the Mid semester, students are divided into several small groups that will discuss the topics of lectures contained in RPS. There are 5 (five) groups that have 5 (five) lecture topics in RPS, where each group consists of 8-9 students. The first group discusses topics concerning character and key nature of Political Integrity, Frame work of Integrity System and pillars of National Integrity. The second group discusses Integrity in several Public sectors. The third group discussed the Conception of Corruption and the Causes of Corruption, the Impact of Corruption and the Strategy for Eradicating Corruption. The fourth group discusses Corruption in the public sector as well as the fifth group discusses political corruption.

The assessment of student learning achievement has fully referred to the SCL method in which the process of granting the evaluation of learning is no longer solely determined by the final results of the student in the form of mid term or final term results, but the assessment is seen from the whole learning process ranging from the results of the midterm exams, the final exam semester, individual and group assignments, attendance, activeness in classroom discussions. Even the assessment is also seen from student activities that support the strengthening of science such as participating in organizing and other student activities, including also noted the ability of students in making opinions in the mass media as well as tulsan articles in various journals.

The assessment system consists of midterm exams (25\%) and Final Semester Exams (25\%) while the assessment process consists of personal and individual tasks and presentations (critical thinking and logical argument skills, teamwork, communication) (20\%) and final tasks in the form of case analysis (technical and analytical capabilities, teamwork, communication with $20 \%$ presentation and activeness with percentage stipulated at $10 \%$. 
For this semester, the spread of $70 \%$ students' score ranges from 70-95 (B to the $\mathrm{A}$ in grade letter), and 30\% get a $\mathrm{C}$ to the $\mathrm{B}$ - grade. In addition, there are some students who are interested in planning the writing of their research proposals with the theme of integrity and anti-corruption. From some of the topics contained in the RPS of this subject, the topic is most in demand by students on the issue of the implementation of integrity and anti-corruption values in the political life of the government in Indonesia both at the central level and in the region.

There are several methods given in the learning process of Integrity and Anti-Corruption subject in the middle of the semester face-to-face scheme, Identifying the learning characteristics of students through pre-test and post test conducted before and after the lecture process is carried out to measure the knowledge and ability of students in understanding the topics in subject RPS, holding study contracts based on active participation of students, designing a classroom atmosphere that can interact with the entire class. At the beginning of the lecture, the lecturer gives an introduction to the material as well as throwing various issues or cases so as to stimulate students to issue their opinions in the form of class discussions and open the widest range of discussions related to the topic of learning. In face-to-face lectures, lecturers at the beginning of lectures have given RPS, lecture modules and lecture contracts to students who are distributed in WAG. At the beginning of the meeting students are also divided into small groups where each group will present the material contained in rps at each meeting and the presentation material must be shared in WAG one day ahead of the lecture schedule.

The following figure describes the face-to-face lecture process before Midterm Test:

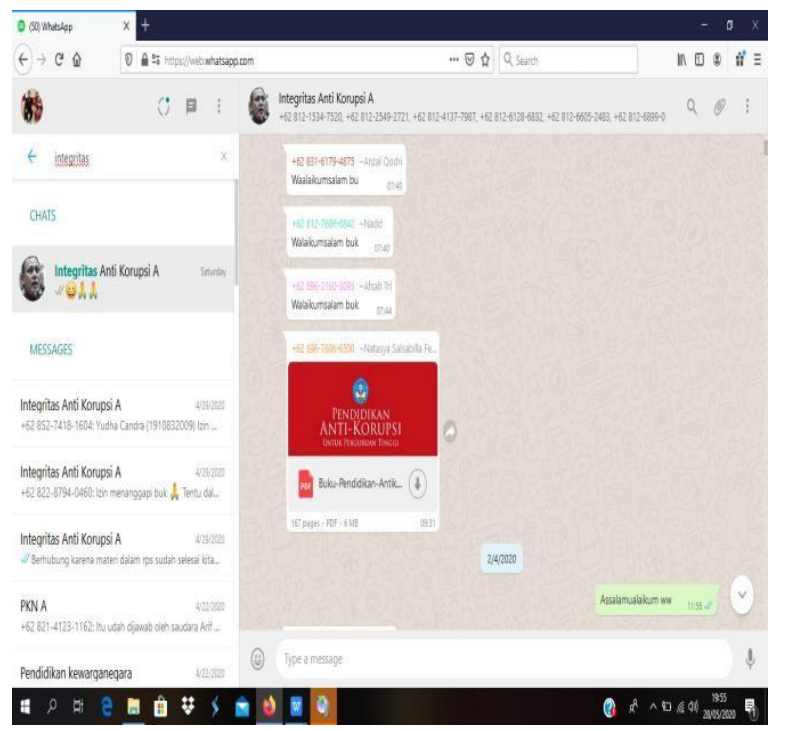

Figure 1. Whatsapp Group (WAG) of this subject

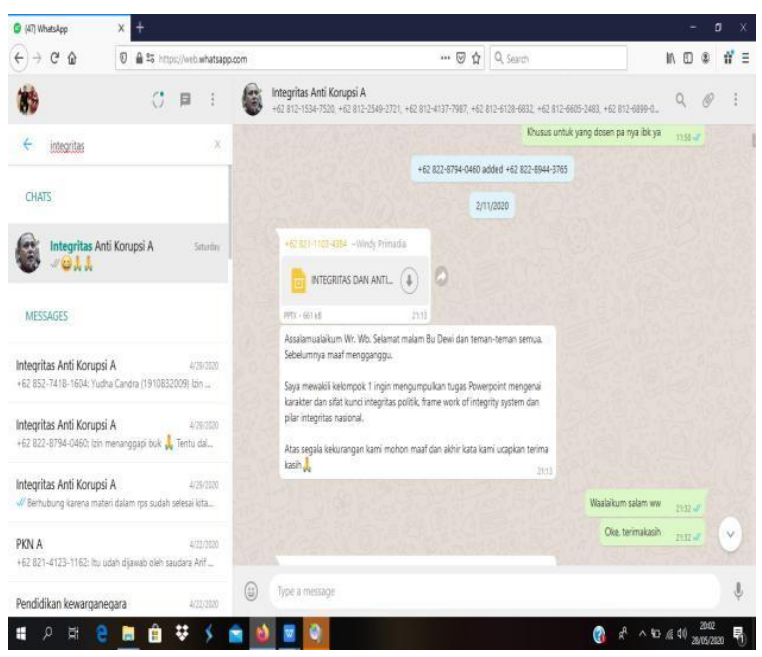

Figure 2. Students already share presentation materials one day before the lecture begins

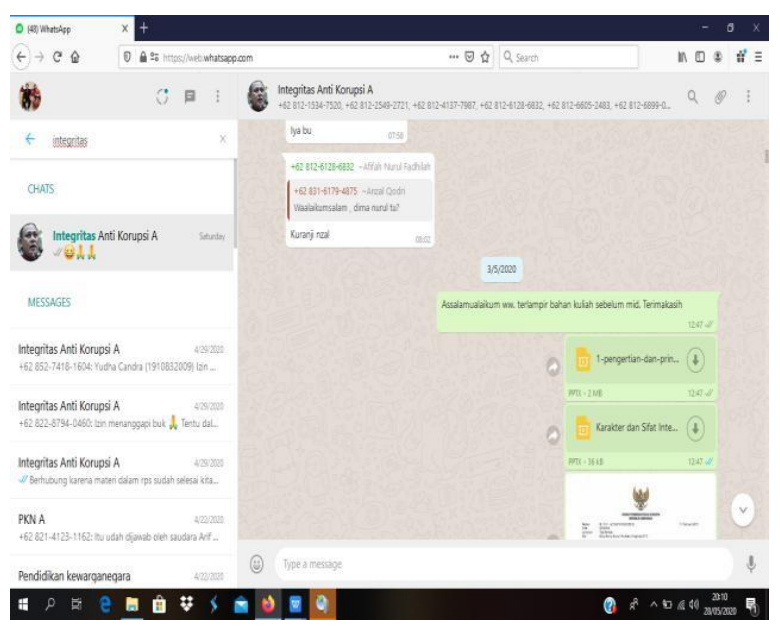

Figure 3. Second module given via WAG

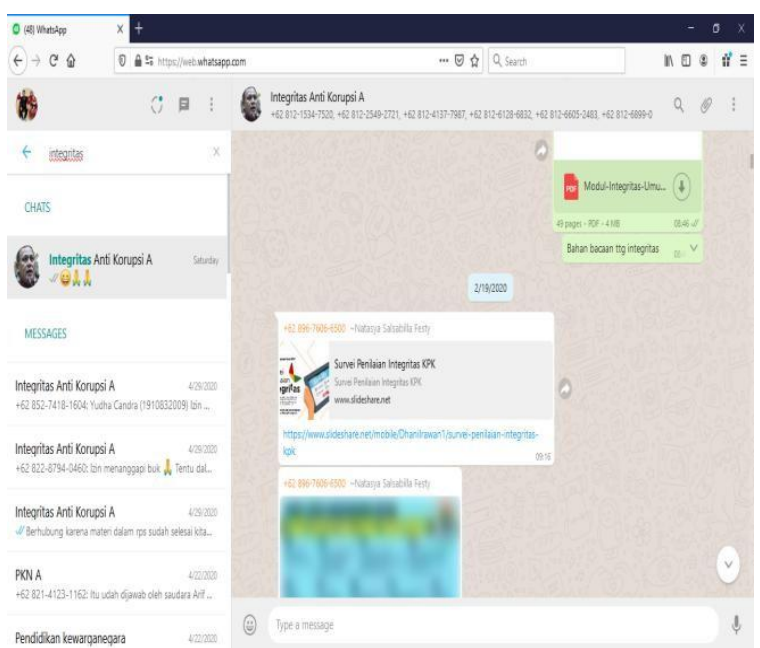

Figure 4. All lecture materials are given by lecturers through WAG before mid term test takes place 


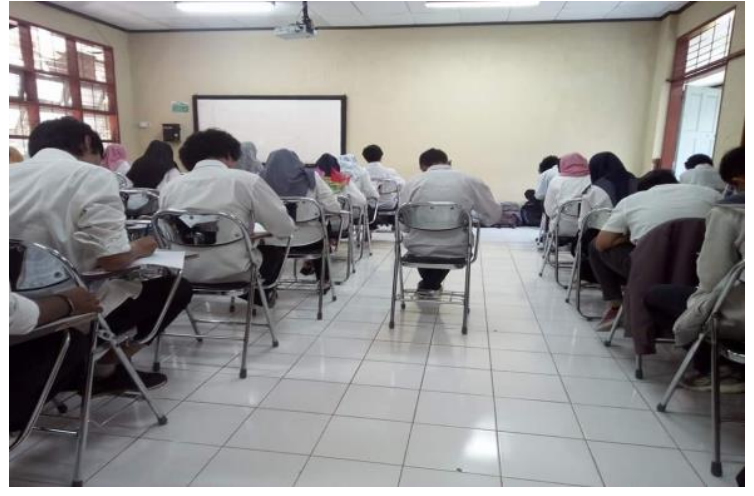

Figure 5. Students carrying out mid term test

In the process after Midterm Semester with online methods, the learning technique used is to study cases related to the topic in subject RPS to be discussed together through WAG. The First Lecture online was agreed with students to use a previously existing course WAG. At this meeting, there is still a theme of face-toface lectures that remain in the group discussion. At the meeting the two students were divided back into several groups that will discuss one topic in RPS that has been revised and adapted to the pattern of online lectures. Where in this meeting discussed the pros and cons of the Minister of Law and Human Rights's statement to free corrupt inmates. At this meeting we use online mass media to dig up information as much as possible and then each group does an argument. At the third meeting, discussed about the actual development of corruption eradication that occurred in Indonesia and students gave their respective arguments and ended with a closing by lecturers. At the next meeting students were given the task of discussing the implementation of integrity values in some cases that are debated by the public, such as the policy of giving pre-employment cards involving the president's special staff, then also discussing the habits of people who bribe when doing public service. In the fifth meeting to the six learning methods are still the same as in the fourth meeting. At the last meeting, a learning evaluation was conducted from the beginning of the meeting to the end of the lecture.

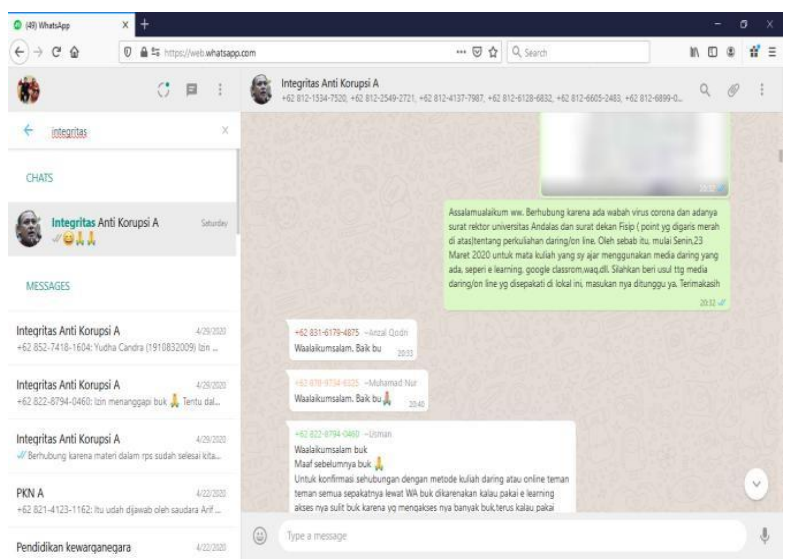

Figure 6. Deal with students use WAG as an online medium

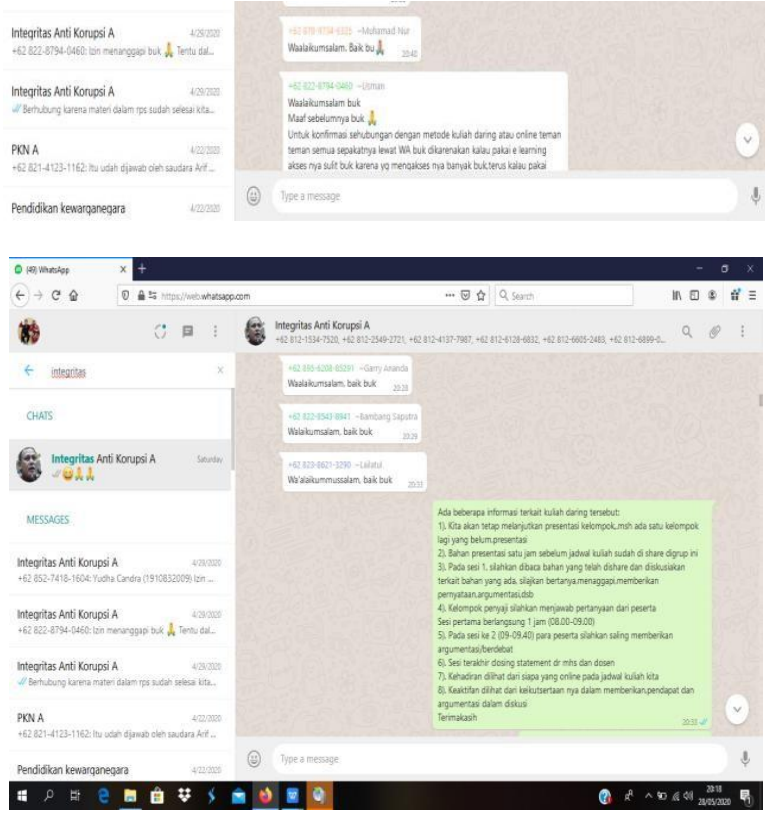

Figure 7. Key points of the process online lectures

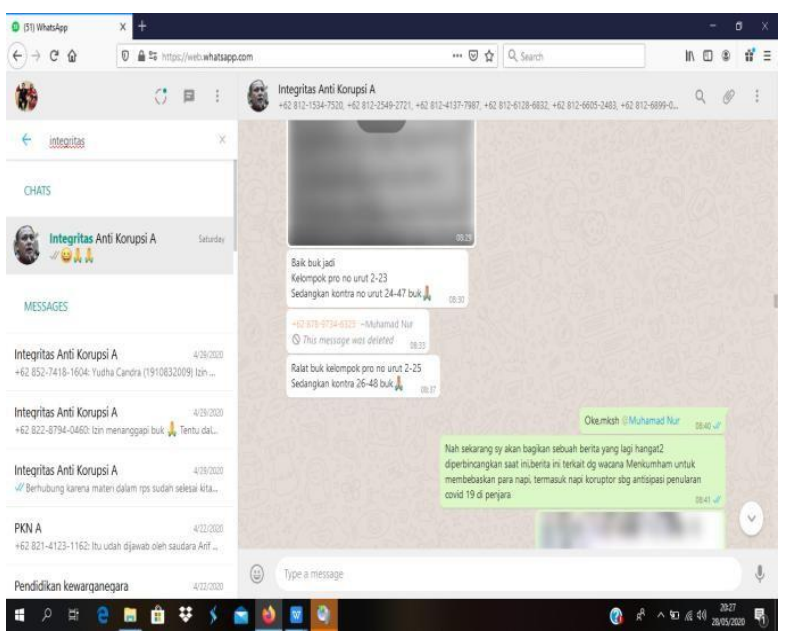

Figure 8. one of the models of media-based online discussion

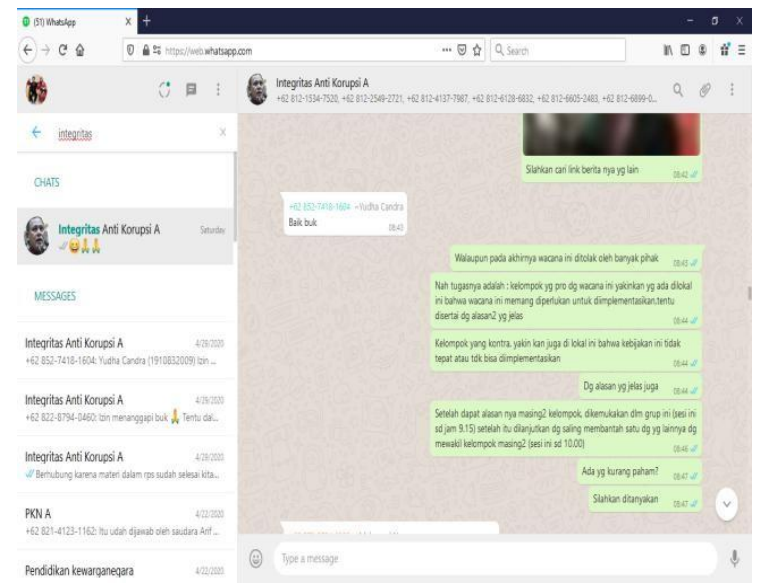

Figure 9. Media-based task instruction 
In the learning process there are several student problems that are often found such as the lack of softskills owned by students as well as the lack of ability of students to communicate and give views at every course learning meeting. And most students do not know or do not understand the updated studies on political and bureaucratic developments, especially regarding formal studies on the development of bureaucracy in Indonesia. This condition is found at first to seventh meetings or before the midterms. At meetings after the midterms, the obstacles that often arise are the problems of the network and internet package of students that become the problem, as well as the lack of control over students who are active / inactive in the discussion process.

\section{CONCLUSION}

In general, the increase in student softskills can be developed by the application of the SCL method, proven by the large number of student responses during class discussions, especially related to communication skills, critical and analytical thinking as well as the ability to solve problems when given a case to solve in groups and individuals

The learning process using the problem base learning and inquiry method can be applied to the lecture process face-to-face or by online methods. However, in online lectures lecturers have difficulty in conducting control over the active involvement of each student in responding to the discussion activities of the case that have been agreed together.

\section{AUTHORS' CONTRIBUTIONS}

Education Quality Development and Assurance Research (PPMP) is a continuation of similar research that has been conducted by researchers, by modifying the development of learning methods from the previous one. In 2017 researchers have won "PTK" (classroom action research) grants as research members (Sri Zul Cahairiyah, Dewi Anggraini, Febriani. 2017. Internship at Women's Institution in West Sumatra. Funded by PTK Fund in 2017). In 2018, researchers also won another PTK grant (Dewi Anggraini,Febriani. 2018 Application of ProblemBased Learning (Pbl) Learning Method in Nagari Government Political subject. Funded by PTK fund in 2018) and in 2019 researchers have also awarded PPMP Grant (Dewi Anggraini, Didi Rahmadi. 2019. Application of Problem-Based Learning And Inquiry (Pbl) Learning Method in Bureaucratic and Political subject. Funded with PPMP 2019 fund.

\section{ACKNOWLEDGMENTS}

This research has been funded by Education Quality Development and Assurance Research grant, LP3M Andalas University (2019) and supported as well by Faculty of Social and Political Sciences Andalas University.

\section{REFERENCES}

[1] Afrizal et al., Panduan Praktis Pelaksanaan Student Centered Learning (SCL). LP3M, Universitas Andalas.

[2] Sri Zulchairiah, D. Anggraini, Febriani, Magang di Lembaga Perempuan, Sumatera Barat: Laporan Penelitian PTK tahun 2017. LP3M Unand, 2017.

[3] D. Anggraini, Febriani, Penerapan Metode Pembelajaran Problem-Based Learning (PBL) Pada Mata Kuliah Politik Pemerintahan Desa/Nagari. Laporan Penelitian PTK tahun 2018. LP3M Unand, 2018.

[4] D. Anggraini, Didi Rahmadi, Penerapan Metode Pembelajaran Problem-Based Learning And Inquiry (PBL) Pada Mata Kuliah Birokrasi Dan Politik. Laporan Penelitian PPMP tahun 2019. LP3M Unand, 2019.

[5] http://www.lubisgrafura.wordpress.com (accessed March, 8, 2020) 